\title{
Post harvest physiological and biochemical changes in guava (cv. LUCKNOW-49) fruits harvested at two stages of maturity during low temperature storage
}

\author{
V. Phani DeEPThi ${ }^{*}$ and R. Chandra SeKhaR ${ }^{2}$ \\ ${ }^{1}$ Horticultural College and Research Institute, Anantharajupet, KADAPA (A.P.) INDIA \\ ${ }^{2}$ Sri Konda Laxman Telangana State Horticultural University, Rajendranagar, HYDERABAD (TELANGANA) INDIA \\ Email : deepthivellaturi@gmail.com \\ *Author for Correspondence \\ Research chronicle : Received : 25.08.2015; Revised : 15.10.2015; Accepted : 17.11.2015
}

SUMMARY :

The present investigation was carried out at Post Harvest Laboratory, College of Horticulture, Rajendranagar, Hyderabad during Nov.-Dec. (2010 and 2011). Skin colour, fruit firmness, pectin content, pectin methyl esterase (PME) activity, respiration and ethylene evolution rates were monitored during cold storage $\left(10 \pm 1^{\circ} \mathrm{C}\right.$ and $\left.90 \pm 5 \% \mathrm{RH}\right)$ of guavas (cv. LUCKNOW-49) harvested at two stages of maturity, mature green (maximum growth of fruits is attained and skin colour changes from dark green to light green) and colour turning (skin colour turns slightly yellow from light green) treated with naphthalene acetic acid (100 and $200 \mathrm{ppm})$, gibberellic acid (150 and $300 \mathrm{ppm}$ ) and benzyl adenine (25 and $50 \mathrm{ppm}$ ). Skin colour (Hunter ' $\mathrm{L}$ ', ' $a$ ' and 'b') increased progressively, while fruit firmness and pectin content decreased consistently with the advancement of storage period. Activity of cell wall degrading enzyme, PME declined gradually till the fruits became ripe, but increased in the over-ripe stage. Likewise, respiration and ethylene production rates also exhibited similar pattern of increase coinciding with ripe stage followed by a decline later. However, the peak in respiration rate was preceded by maximum ethylene production in guava during storage at $10 \pm 1^{\circ} \mathrm{C}$. Mature green (MG) stage fruits showed promising results in delaying the physiological and biochemical changes compared to colour turning (CT) stage and among the treatments, fruits treated with BA (50 ppm) exhibited longer shelf-life and acceptable fruit quality during cold storage.

KEY WORDS : Lucknow-49, Mature green, Colour turning, NAA, GA, BA, PME, $\mathrm{CO}_{2}$ and $\mathrm{C}_{2} \mathrm{H}_{4}$

How to cite this paper : Deepthi, V. Phani and Sekhar, R. Chandra (2015). Post harvest physiological and biochemical changes in guava (cv. LUCKNOW-49) fruits harvested at two stages of maturity during low temperature storage. Internat. J. Proc. \& Post Harvest Technol., 6 (2) : 128-143. 